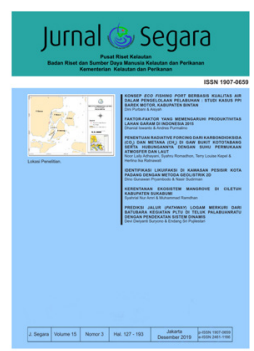

JURNAL SEGARA

http://ejournal-balitbang.kkp.go.id/index.php/segara

ISSN : 1907-0659

e-ISSN : 2461-1166

Nomor Akreditasi: 766/AU3/P2MI-LIPI/10/2016

\title{
IDENTIFIKASI LIKUIFAKSI DI KAWASAN PESISIR KOTA PADANG DENGAN METODA GEOLISTRIK 2D
}

\section{IDENTIFICATION LIQUEFACTION IN COASTAL AREA OF PADANG CITY WITH 2D GEOELECTRIC METHOD}

\author{
Dino Gunawan Pryambodo \& Nasir Sudirman \\ Pusat Riset Kelautan, BRSDM - KKP \\ JIn. Pasir Putih 1 Ancol Jakarta; Telp/fax : +62 2164711583
}

Diterima: 1 Maret 2018; Diterima Setelah Perbaikan: 9 Desember 2019; Disetujui Terbit: 15 Desember 2019

\begin{abstract}
ABSTRAK
Studi kasus penyelidikan likuifaksi dilakukan di kawasan pesisir kota Padang, yang terletak di pesisir barat Sumatra, pada zona ini sering tejadinya gempa bumi. Prediksi dari zona likuifaksi ini daerah kegempaan yang tinggi akan sangat membantu untuk mitigasi bahaya bencana gempa bumi. Geolistrik 2D menggunakan konfigurasi Wenner telah dilakukan dan bisa membantu untuk menggambarkan zona likuifaksi. Lintasan geolistrik ini terdiri dari empat lintasan yaitu lintasan UBH, lintasan Parak Gadang, lintasan Purus dan lintasan Telkom dengan bentangan kabel sepanjang 160 meter dan dengan kedalaman penetrasi sedalam 26,5 meter. Dengan latar belakang ini, bahwa dalam hubungannya dengan karakteristik tanah dan sedimen menunjukkan hubungan yang tinggi terhadap likuifaksi, dan anomali nilai tahanan jenis akan memberikan informasi penting untuk memprediksi dan mengidentifikasi zona likuifaksi. Hasil dari penelitian ini mengungkapkan lapisan bawah permukaan terdiri dari endapan aluvial yang jenuh air sehingga berpotensi menjadi likuifaksi selama terjadinya gempa bumi. Pada model 2-D geolistrik ini dengan nilai tahanan jenisnya rendah $<2 \Omega \mathrm{m}$ dan dengan kedalaman rata-rata kurang dari 10 meter dan di lintasan Telkom di beberapa tempat kedalaman likuifaksinya mencapai 20 meter.
\end{abstract}

Kata kunci : Likuifaksi, Pesisir Kota Padang, Geolistrik 2D, Gempa Bumi.

\section{ABSTRACT}

A case study of liquefaction investigation was carried out in the coastal of Padang city, located on the west coast of Sumatra, in this zone of occurrence of earthquakes frequently. Prediction of the liquefaction zone is the area of high seismicity will be very helpful for earthquake hazard mitigation. 2D geoelectric using Wenner configuration has been done and can help to describe the liquefaction zone. Geoelectric lines consists of four tracks that UBH line, Parak Gadang line, Purus line and Telkom line with a stretch of 160-meter long cable and with a penetration depth of 26.5 meters deep. With this background, that in conjunction with the characteristics of soils and sediments showed high correlation to liquefaction, and anomalous resistivity value will provide important information for predicting and identifying the liquefaction zone. The results of this study reveal the subsurface is composed of alluvial deposits becomes saturated with water, so the potential of liquefaction during an earthquake. In model 2-D geoelectric low resistivity value $<2 \Omega m$ and with an average depth of less than 10 meters and on Telkom line liquefaction depth in some places reaches 20 meters.

Keywords: Liquefaction, coastal of Padang city, Geoelectric 2D, Earthquakes.

Corresponding author:

JI. Pasir Putih I Ancol Timur, Jakarta Utara 14430. Email: dinogunawan77@gmail.com 


\section{PENDAHULUAN}

Kota Padang secara geografis terletak di wilayah pesisir pantai barat Sumatera (Gambar 1), merupakan ibukota Provinsi Sumatera Barat yang menyebabkan aktifitas masyarakat banyak terpusat di kota tersebut. Banyak objek vital dan fasilitas umum/fasilitas sosial yang mendukung kehidupan di Kota Padang tertumpu di wilayah pesisir pantai barat Sumatera tersebut, karena kota Padang terletak di wilayah pesisir pantai barat Sumatera maka memiliki kerentanan bahaya gempa bumi yang tinggi karena di sebelah timur Kota Padang terdapat zona subduksi Sumatera yang bergerak sekitar $40 \mathrm{~s} / \mathrm{d} 70 \mathrm{~mm}$ per tahun (Natawidjaja, 2004). Pada 30 September 2009 telah terjadi gempa yang cukup besar di Sumatera Barat dengan dengan kekuatan 7,6 SR pada kedalaman $71 \mathrm{~km}$ yang mengakibatkan banyak bangunan di kota Padang dan sekitarnya runtuh karena kekuatan getaran yang cukup tinggi (Setyonegoro, 2013).

Geologi pantai barat Sumatera pada bagian pesisir hingga perbukitan secara umum terbentuk oleh endapan sedimen yang berumur kuarter dengan susunan lapisan pasir kerikilan-lempung, lanau, pasir yang dapat mencapai ketebalan mulai 5 meter hingga mencapai 200 meter (Gambar 2) (Kastowo et al., 1994) sehingga bisa menimbulkan dampak likuifaksi. Likuifaksi ádalah fenomena perubahan perilaku lapisan pasir yang jenuh air menjadi seperti cairan akibat beban getaran gempa bumi. syarat-syarat terjadinya peristiwa likuifaksi harus memenuhi kriteria sebagai berikut yaitu lapisan tanahnya berupa pasir atau lanau, lapisan tanahnya jenuh air, lapisan tanahnya bersifat terurai atau gembur (tidak padat) (Muntohar, 2010).

Meskipun terdapat lapisan tanah yang berpotensi likuifaksi dan sejumlah peristiwa gempa bumi besar di Kota Padang. Bencana akibat likuifaksi kemungkinan akan sangat signifikan mengingat aktifitas tektonik di busur Sumatera dan kepadatan penduduk dan bangunan di wilayah pesisir Kota Padang tersebut. Kota Padang yang berada di wilayah pesisir rawan terhadap bahaya likuifaksi (Chang et al., 2004). Pengetahuan bahaya likuifaksi ini sangat penting dalam rangka melakukan usaha mitigasi yang disesuaikan dengan derajat kerentanan terhadap bahaya likuifaksi di wilayah ini.

Metoda geofisika adalah suatu metoda penyelidikan yang sering digunakan untuk mengambarkan interior bawah permukaan bumi untuk memberikan informasi - informasi mengenai kondisi geologi bawah permukaan bumi, salah satu informasi yang dapat diberikan adalah tentang adanya indikasi adanya likuifaksi (Syukri, 2011).

\section{METODE PENELITIAN}

Metode geolistrik merupakan metode geofisika yang dapat digunakan untuk mengidentifikasi keberadaan likuifaksi di bawah permukaan tanah. Nilai tahanan jenis batuan bergantung pada formasi batuan, temperature, komposisi mineral penyusun, porositas dan bentuk pori, saturasi fluida, dan konduktifitas elektrik fluida formasi (Barker, 1981). Peningkatan konsentrasi ion pada fluida akan meningkatkan konduktifitas fluida dan menurunkan nilai tahanan jenisnya yang akan mempengaruhi batuan secara keseluruhan. Satuan tahanan jenis yang digunakan adalah $\Omega \mathrm{m}$ (Ohm meter) (Hasanudin \& Pryambodo, 2009). Beberapa penelitian terdahulu membuktikan bahwa pengaruh kandungan air akan menurunkan nilai tahanan jenis suatu batuan, besar kecilnya penurunan nilai tahanan jenis tergantung pada

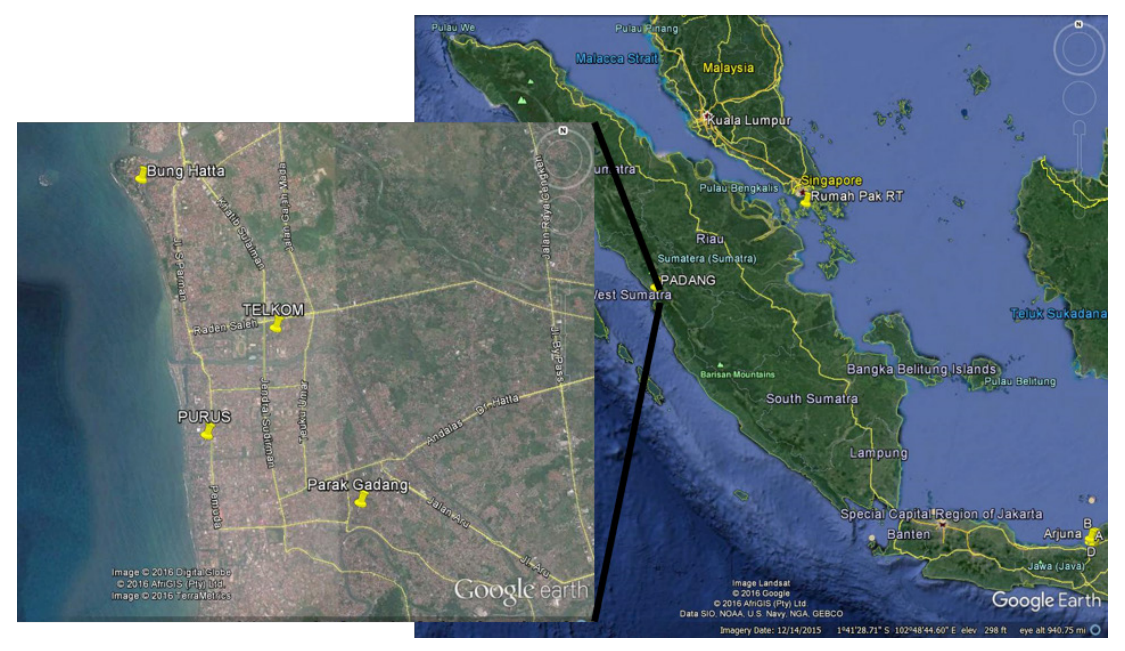

Gambar 1. Lokasi Penelitian di Kota Padang

(054'30.40"S-0 $0^{\circ} 57^{\prime} 1.85^{\prime \prime S}$ dan $\left.100^{\circ} 20^{\prime} 41.76 " \mathrm{E}-100^{\circ} 22^{\prime} 21.13^{\prime \prime E}\right)$. 


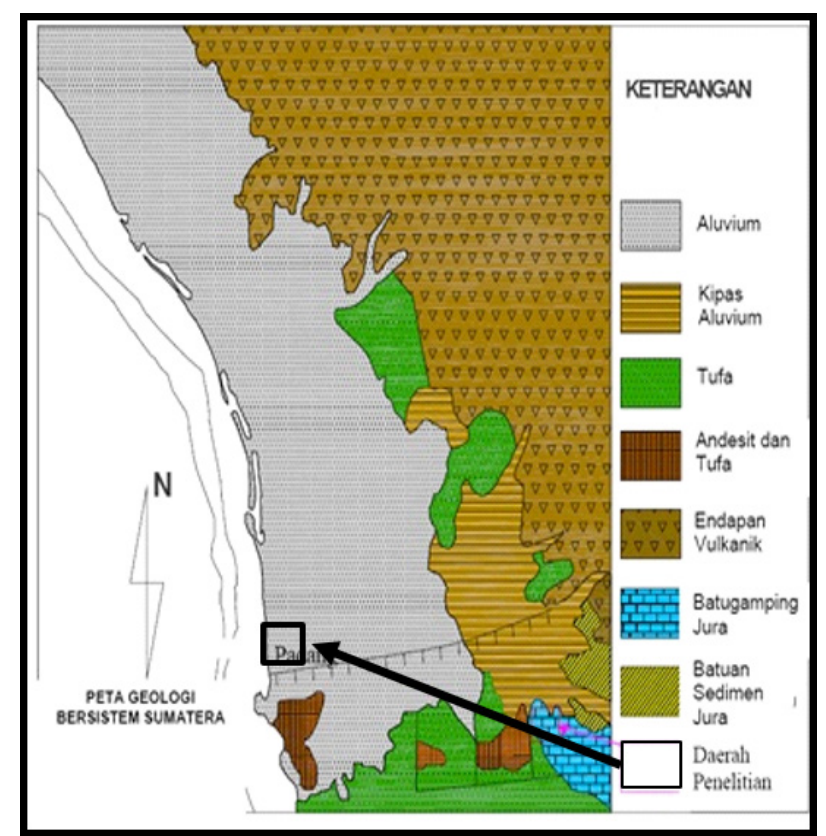

Gambar 2. Gambaran geologi lembar padang.

kandungan air yang ada di dalam pori-pori batuan (porositas batuan) (Santoso, 2002).

Likuifaksi adalah proses mekanik dari prilaku lapisan pasir yang jenuh air menjadi seperti cairan akibat beban getaran gempa bumi, untuk mengidentifikasi wilayah mana yang rentan terhadap likuifaksi maka perlu penelitan bawah permukaan tanah dengan metoda geofisika khususnya dengan metoda geolistrik, karena metoda geolistrik ini dapat mengidentifikasikan zona jenuh air di bawah permukaan tanah (Reynolds, 1977) seperti penjelasan diatas sehingga bisa mengetahui wilayah yang rentan terhadap bahaya likuifaksi.

Survei dilakukan dengan menggunakan alat survei GPS (Global Positioning System) Garmin tipe
60 CSx untuk menentukan posisi stasiun dan resistivitymeter Naniura NRD 22 S (Marpaung, 2000) (Gambar 3) untuk mengukur nilai beda potensial sesuai dengan konfigurasi elektrode yang digunakan. Peralatan lain yang digunakan dalam pengukuran mencakup elektroda potensial, elektrode arus, accumulator, dan kabel, dan perlengkapan pendukung seperti meteran, kalkulator, multi tester, dan handy talky $(\mathrm{HT})$.

Metoda geolistrik 2D atau electrical imaging digunakan untuk melihat pola perubahan tahanan jenis batuan baik secara vertikal maupun secara horizontal dibawah permukaan tanah. Konfigurasi elektroda yang digunakan untuk pengukuran ini sama dengan pengambilan data geolistrik cara sounding atau 1D, tetapi teknik pengambilan data yang sedikit berbeda

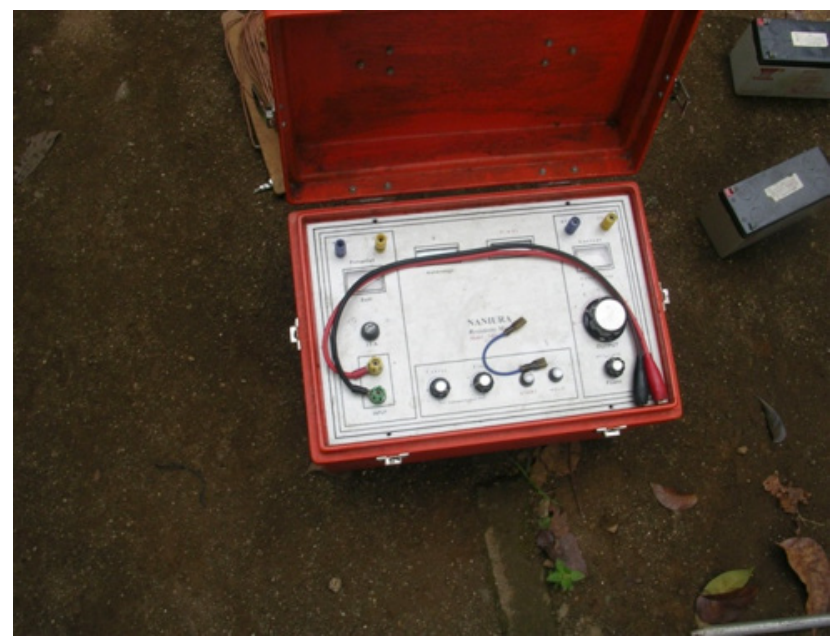

Gambar 3. Resistivitymeter Naniura NRD 22 S. 


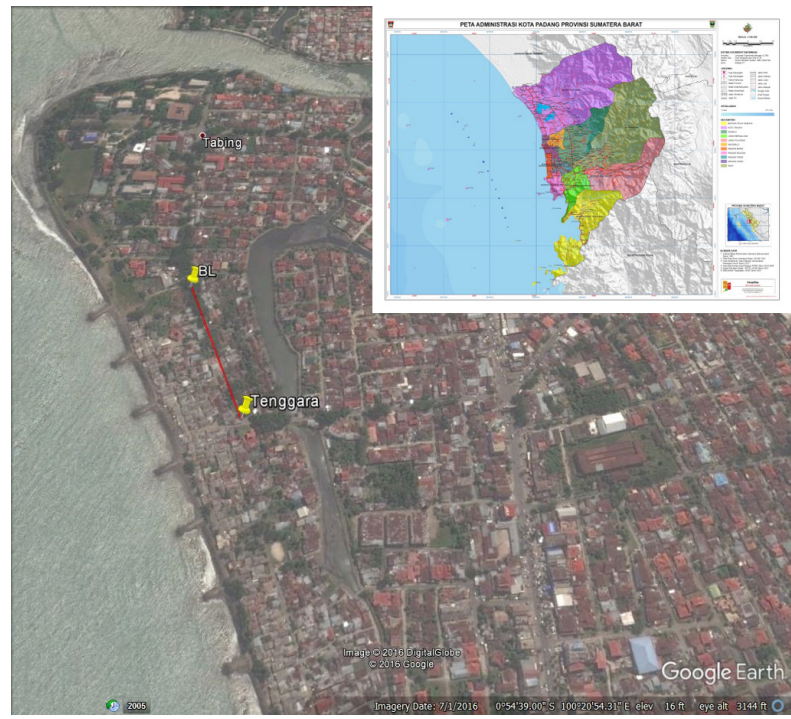

Gambar 4. Lintasan UBH.

(Loke, 1999). Survey dilakukan pada lintasan yang lurus. Jumlah elektroda adalah 32 dengan jarak antar elektroda adalah 10 meter, maka panjang lintasan pengukuran adalah 310 meter.

Metode akuisisi data lapangan yang dipergunakan dalam penelitian adalah Konfigurasi Wenner seperti Gambar 3, cara ini dipakai untuk mengetahui variasi harga tahanan jenis secara lateral dan vertikal, konfigurasi ini dipakai untuk mengetahui kecenderungan harga tahanan jenis di suatu areal tertentu. Setiap lintasan memiliki beberapa titik pengukuran. Untuk mendapatkan nilai tahanan jenis semu dengan konfigurasi wenner maka di gunakan formula seperti berikut (Telford et al., 1990):

$$
\rho_{a}=K \frac{\Delta V}{I}
$$

$$
K=2 \pi a
$$

di mana,

$\rho a=$ Tahanan jenis semu (ohm-m)
$\mathrm{K}=$ Faktor Geometri

$\Delta \mathrm{V}=$ Beda potensial $(\mathrm{mV})$

$\mathrm{I}=$ Kuat arus yang dialirkan (milliAmpere)

$\mathrm{a}=$ Jarak antara kedua elektrode arus $(\mathrm{A}-\mathrm{B})$ dan elektroda potensial $(\mathrm{M}-\mathrm{N})$

Pengukuran dilakukan setahap demi setahap dimulai dari nomor elektroda kecil dan tiap layer kedalaman (n). Setelah semua data diambil, jika diplot maka akan diperoleh kumpulan data yang menyerupai perahu terbalik (Loke, 1999). Pada Gambar 4 diilustrasikan konfigurasi dari peralatan, kabel, dan sebaran titik pengukuran terhadap lapisan kedalaman. Setelah semua data didapatkan, maka dilakukan pengolahan data sehingga diperoleh penampang tahanan jenis dari lintasan yang diambil baik secara vertikal maupun horizontal atau kedalaman. Contoh kasus adalah pada konfigurasi elektroda Wenner dengan jarak elektroda "a" maka langkah pertama yang dilakukan adalah mengukur array elektroda 1a tempat elektroda nomor 1, 2, 3, dan 4 digunakan untuk pengukuran. Konfigurasi ini bergerak sejauh 1a. Setelah pengambilan data untuk spasi $1 \mathrm{a}$, langkah

\section{Tenggara}

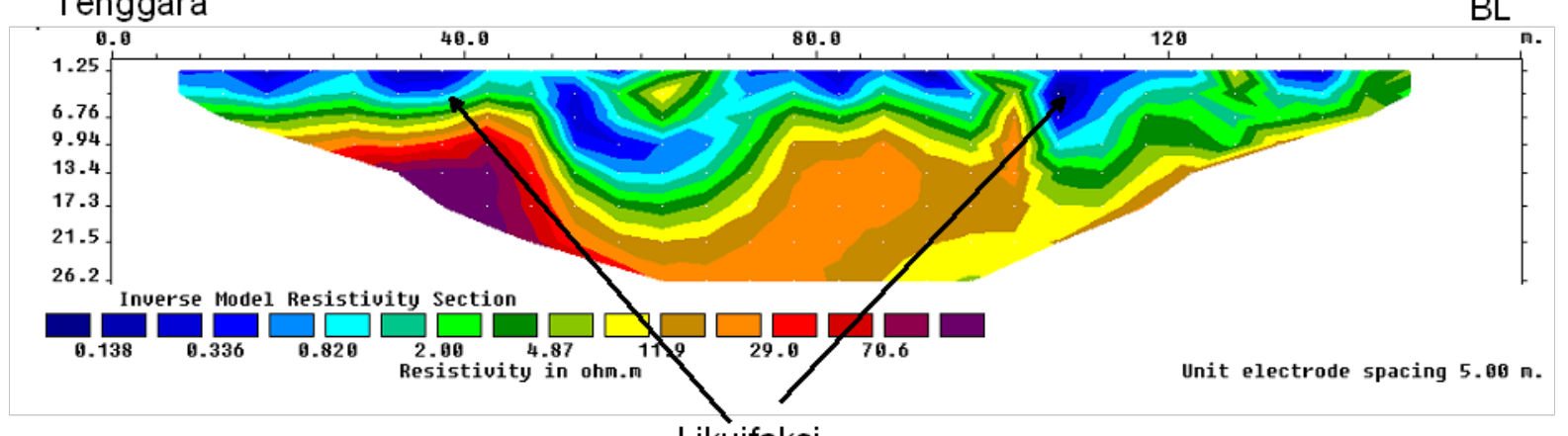

Likuifaksi

Gambar 5. Zona Potensi Likuifaksi Lintasan UBH. 
Tenggara

$\mathrm{BL}$

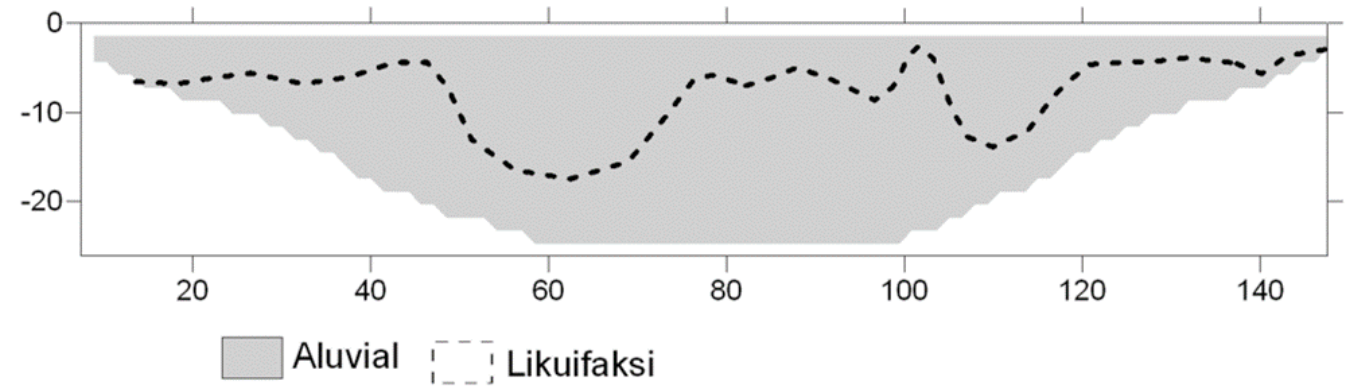

Gambar 6. Litologi Penampang Lintasan UBH.

berikutnya adalah dengan spasi elektroda $2 a$ dan menggunakan elektroda nomor 1, 3, 4 dan 7; pengukuran data terus dilakukan sampai elektroda terakhir.

\section{HASIL DAN PEMBAHASAN}

Hasil pengukuran geolistrik untuk melihat likuifaksi di kota Padang terdapat empat lintasan geolistrik yaitu lintasan UBH (Universitas Bung Hatta), Parak Gadang, Purus dan TELKOM. Dari penampang geolistrik bawah permukaan dapat diinterpretasikan litologi bawah permukaan berdasarkan nilai tahanan jenis hasil pembacaan alat geolistrik sehingga bisa di tentukan daerah likuifaksinya. Pengukuran geolistrik ini untuk empat lokasi ini memakai bentangan kabel geolistrik sepanjang 160 meter dengan kedalaman penetrasi sekitar 26,5 meter di bawah permukaan tanah.

\section{Lintasan UBH}

Lintasan UBH (Universitas Bung Hatta) berarah Tenggara-Barat laut (Gambar 4) dengan panjang bentangan kabel geolistrik sepanjang 160 meter yang berada di dekat pantai dengan kedalaman penetrasi sekitar 26,5 meter di bawah permukaan tanah. Hasil dari geolistrik Wenner 2D didapat suatu citra bawah permukaan tanah (Gambar 5) yang dapat mengidentifikasikan likuifaksi.

Hasil penampang geolistrik lintasan UBH lalu di buat penampang litologi bawah permukaannya (Gambar 6) yang tersusun dari aluvial dengan nilai tahanan jenis < $70 \Omega \mathrm{m}$ (Palacky, 1987). Zona potensi likuifaksi lintasan UBH ini terdapat pada kedalaman kurang dari 15 meter, karena lintasan ini terletak pada tepi pantai sehingga terjadi intrusi air laut kedaratan sehingga lapisan aluvialnya jenuh dengan air laut yang ditunjukkan dengan nilai tahanan jenis yang kecil $<2$ $\Omega \mathrm{m}$, sehingga bisa mengakibatkan lapisan aluvial ini menjadi jenuh dengan air laut (zona likuifaksi) dan berbahaya jika terjadi gempa bumi yang besar bias mengakibatkan bencana likuifaksi didaerah tersebut. kemungkinan aluvial ini berasal dari endapan rawa Tohari, 2011).

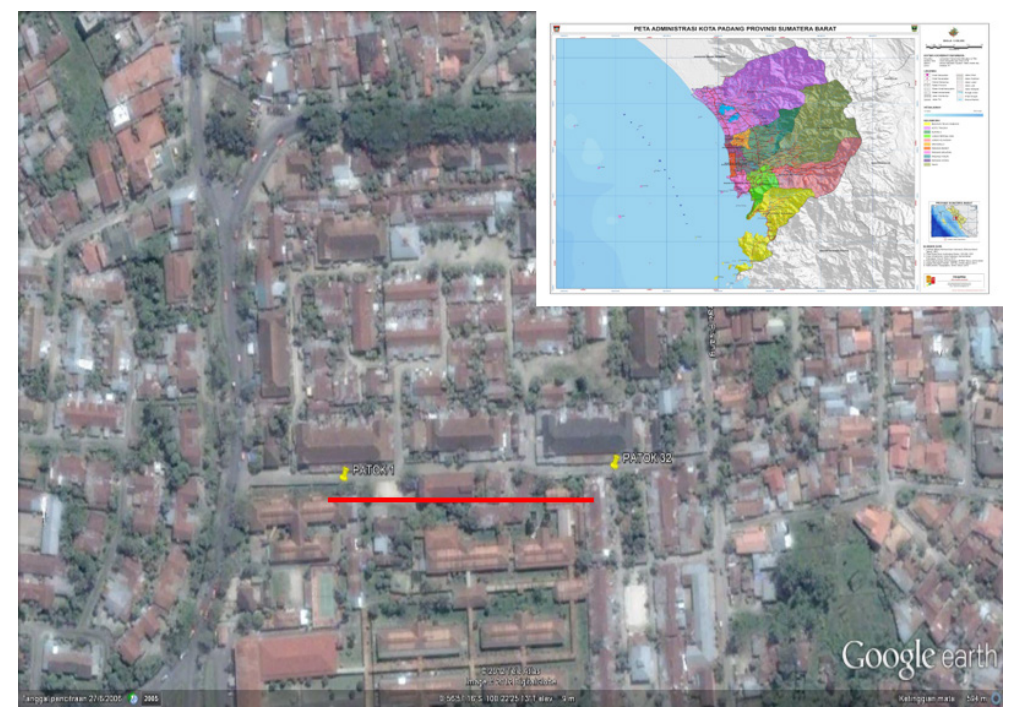

Gambar 7. Lintasan Parak Gadang. 


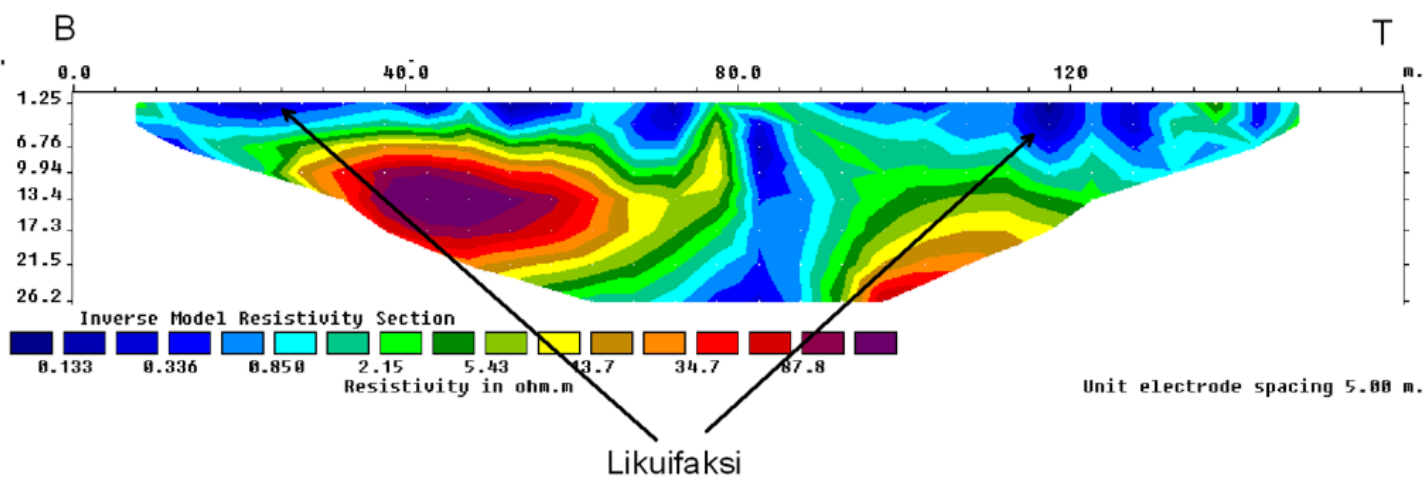

Gambar 8. Zona Likuifaksi Lintasan Parak Gadang.

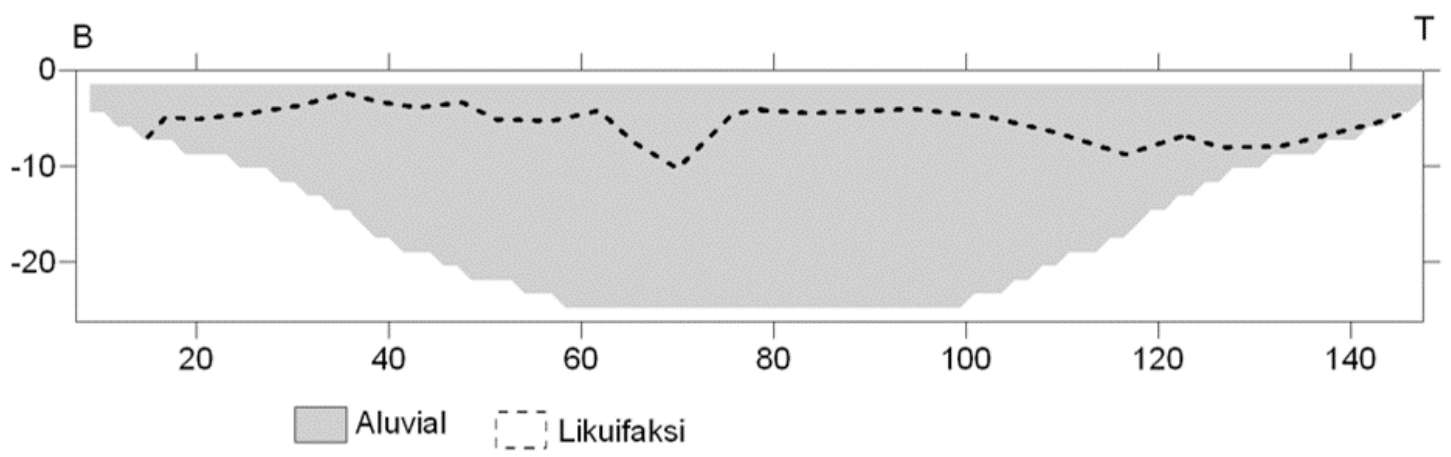

Gambar 9. Litologi Penampang Lintasan Parak Gadang.

\section{Lintasan Parak Gadang}

Lintasan parak Gadang berada di daerah pemukiman yang cukup padat, lintasan ini berarah Barat - Timur (Gambar 7) dengan panjang bentangan kabel geolistrik sepanjang 160 meter dengan kedalaman penetrasi sekitar 26,5 meter di bawah permukaan tanah. Hasil dari geolistrik Wenner 2D didapat suatu citra bawah permukaan tanah (Gambar 8) yang dapat menduga keberadaan zona likuifaksi.
Pada penampang lintasan Parak Gadang terlihat gambaran litologi bawah permukaannya (Gambar 9) tersusun dari aluvial dengan nilai tahanan jenis $<80$ $\Omega \mathrm{m}$. Dari hasil tersebut teridentifikasi zona likuifaksi berada pada kedalaman $<10$ meter garis putus-putus, pada zona ini terlihat akibat likuifaksi terlihat dengan jelas dengan diidentifikasiknnya beberapa bangunan rumah yang ambruk dan amblas. Dari hasil geolistrik 2D di daearah ini nilai tahanan jenis yang kecil $<2$ $\Omega m$, nilai tahanan jenis yang kecil ini diidentifikasikan

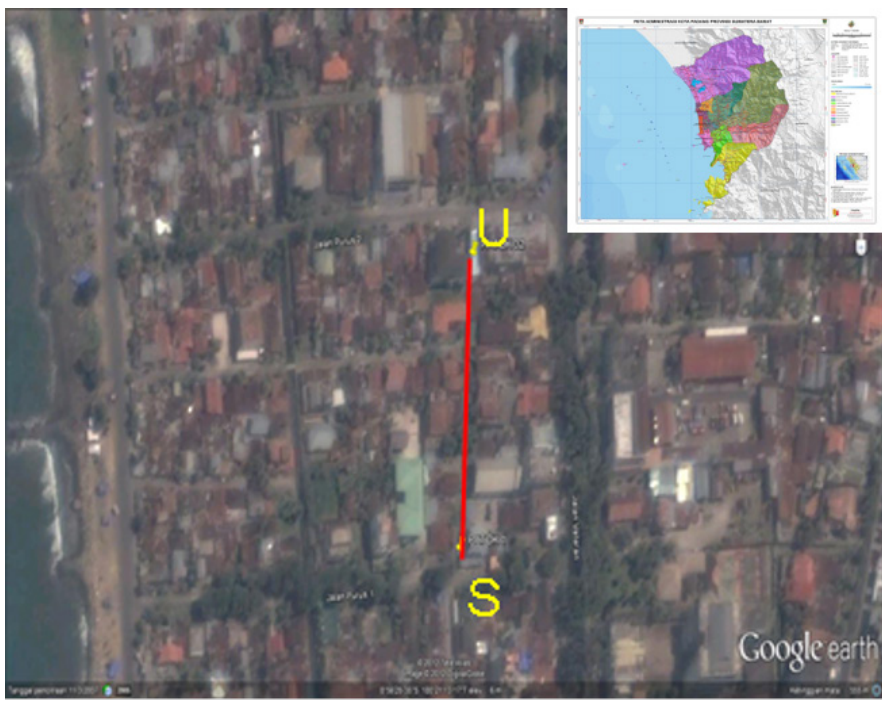

Gambar 10. Lintasan Purus. 


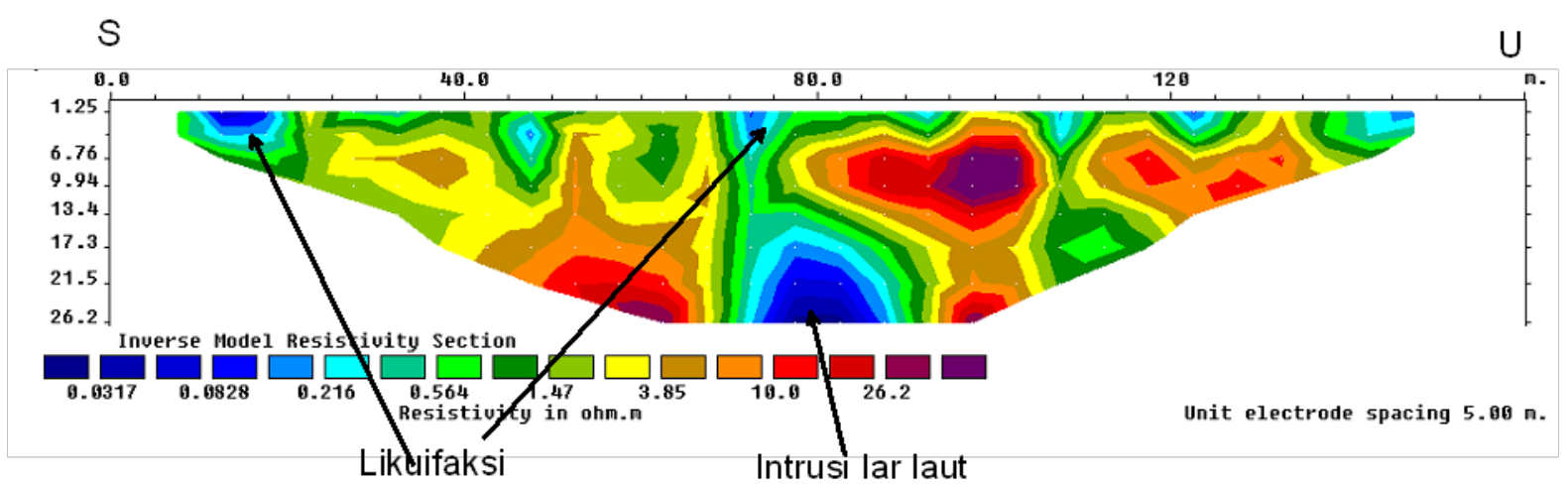

Gambar 11. Zona Potensi Likuifaksi Lintasan Purus.

sebagai zona jenuh dengan fluida (air) sehingga lapisan endapan aluvialnya jenuh dengan air sehingga ketika terjadi gempa bumi besar bisa berbahaya karena bisa terjadi fenomena likuifaksi.

\section{Lintasan Purus}

Lintasan Purus berada di daerah pemukiman yang cukup padat penduduknya dan dekat dengan garis pantai yang berjarak 250 meter, lintasan ini berarah Utara - Selatan (Gambar 10) dengan panjang bentangan kabel geolistrik sepanjang 160 meter dengan kedalaman penetrasi sekitar 26,5 meter di bawah permukaan tanah. Hasil dari geolistrik Wenner
2D didapat suatu penampang bawah permukaan tanah (Gambar 11) dan dapat menduga keberadaan zona likuifaksi.

Pada penampang lintasan Purus terlihat penampang litologi bawah permukaannya (Gambar 12) tersusun dari aluvial dengan nilai tahanan jenis < $26 \Omega \mathrm{m}$. Dari hasil tersebut terlihat bahwa pada kedalaman < 10 meter, aluvial jenuh terisi air sehingga akan menjadi lunak dengan nilai tahanan jenis yang kecil < $2 \Omega$ m (garis putus-putus) sehingga bisa menjadi zona likuifaksi apabila terjadi gempa bumi, dan pada kedalaman 15 meter terdapat indikasi adanya intrusi

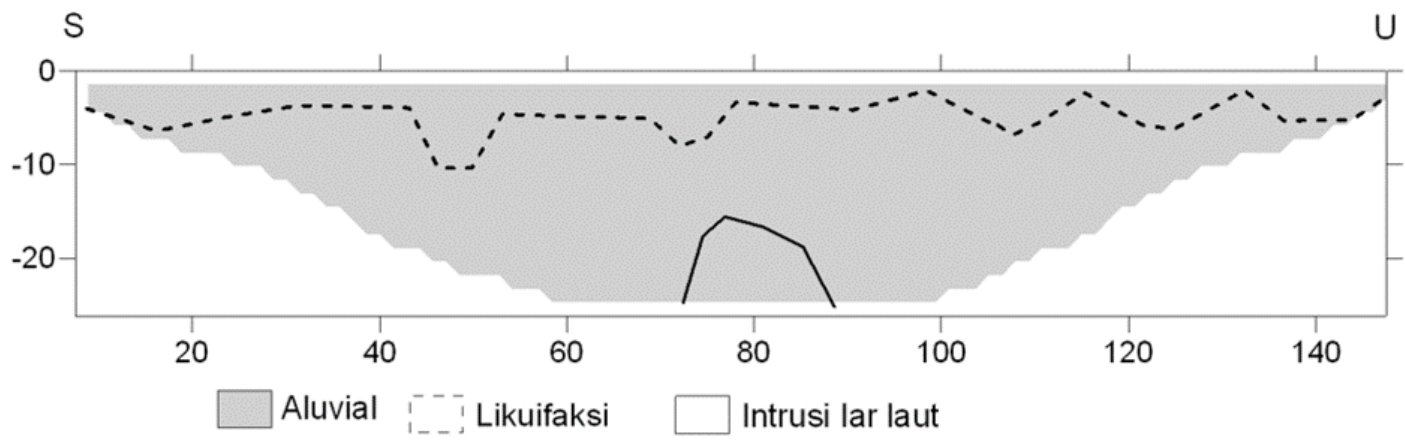

Gambar 12. Litologi Penampang Lintasan Purus.

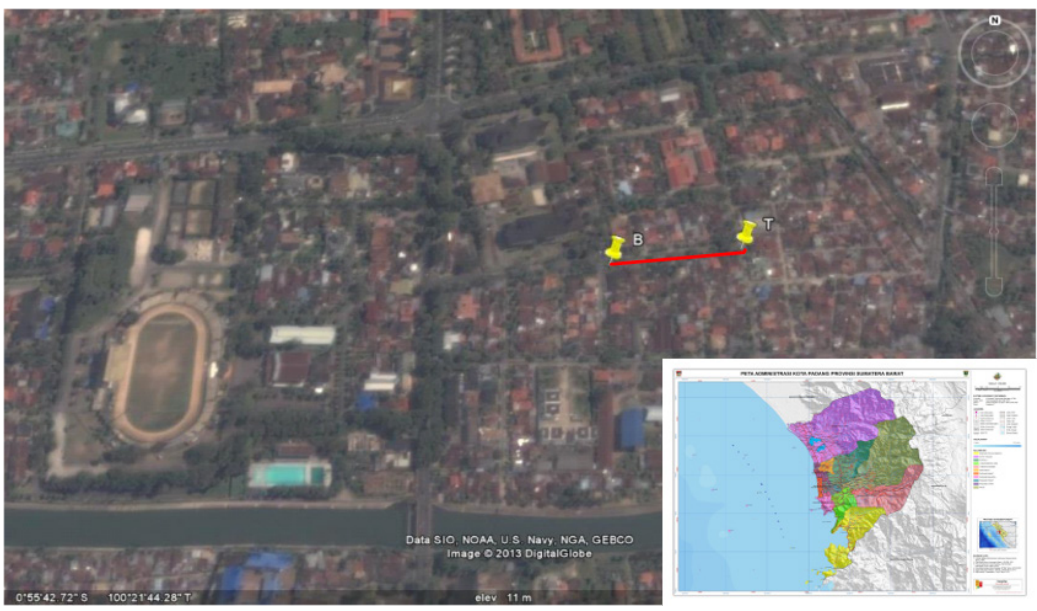

Gambar 13. Lintasan TELKOM. 


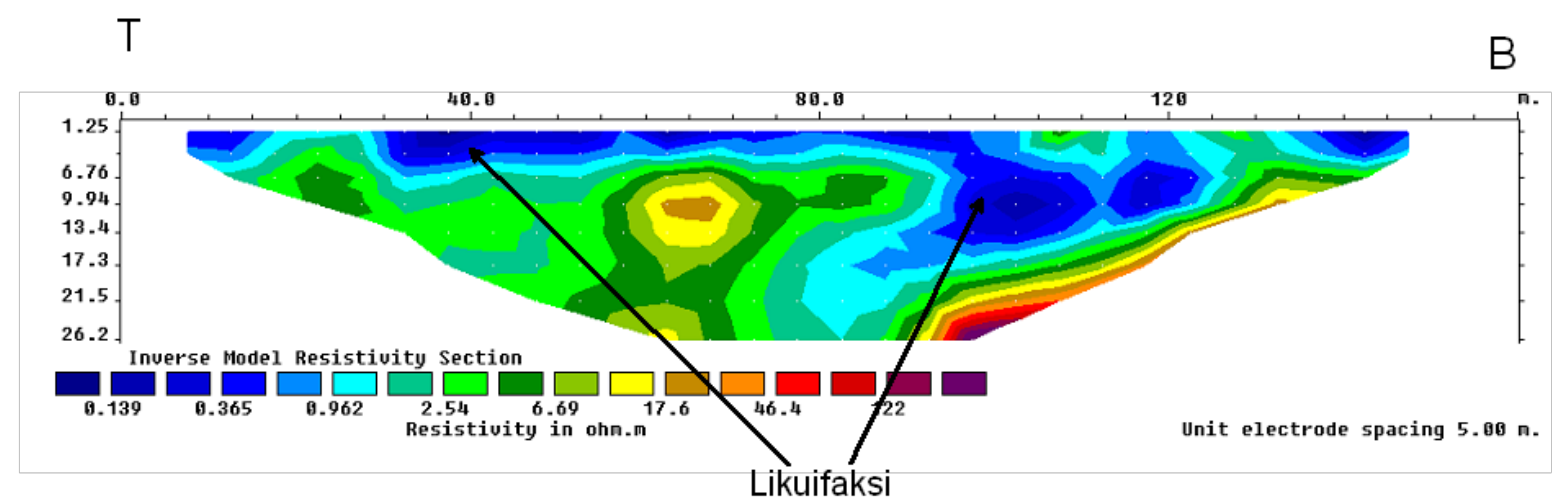

Gambar 14. Zona Likuifaksi Lintasan TELKOM.

air laut dengan nilai tahanan jenis $<0,2 \Omega \mathrm{m}$ (Milsom, KESIMPULAN

2003) karena lintasan ini dekat dengan garis pantai.

\section{Lintasan Telkom}

Lintasan Telkom berada di tengah kota yang penduduknya yang cukup padat, lintasan ini berarah Barat - Timur (Gambar 13) dengan panjang bentangan kabel geolistrik sepanjang 160 meter dengan kedalaman penetrasi sekitar 26,5 meter di bawah permukaan tanah. Hasil dari geolistrik Wenner 2D ini didapat suatu penampang bawah permukaan tanah (Gambar 14) yang dapat menduga keberadaan zona likuifaksi

Pada penampang lintasan Telkom terlihat gambaran litologi bawah permukaannya (Gambar 15) tersusun dari aluvial dengan nilai tahanan jenis $<122$ $\Omega \mathrm{m}$. Dari hasil tersebut terlihat pada kedalaman $<20$ meter, Di daerah ini indikasi adanya likuifaksi dapat terlihat dari beberapa bangunan yang amblas setelah kejadian gempa, likuifaksi di daerah ini terjadi karena endapan aluvial yang ada telah terisi oleh air sehingga menjadi jenuh air hal ini ditunjukkan dengan nilai tahanan jenis yang kecil $<2 \Omega \mathrm{m}$ sehingga ketika terjadi bencana gempa bumi yang besar maka akan menjadi suatu zona likuifaksi dan bias merusak bangunan yang di atasnya.

Penelitian ini menggambarkan penerapan metodologi geolistrik 2D untuk karakterisasi potensi likuifaksi di wilayah pesisir kota Padang. Di sini, dapat diketahui untuk bagian model yang menunjukkan respon yang baik dengan daerah rendah nilai tahanan jenisnya kecil $<2 \Omega \mathrm{m}$, yang litologi batuannya tersusun dari endapan aluvial yang jenuh dengan air hal ini bisa menjadi zona potensi likuifaksi. Kedalaman zona potensi likuifaksi ini rata-rata kurang dari 10 meter dan di beberapa tempat bisa mencapai kedalaman 20 meter, hal ini bias menjadi bahaya karena dapat merusak infrastruktur diatasnya, hasil penelitian ini bias menjadi bahan masukan untuk mitigasi bahaya bencana gempa bumi.

\section{PERSANTUNAN}

Ucapan terimakasih kami sampaikan kepada Loka Riset Sumber Daya Dan Kerentanan Pesisir KKP (Bungus, Padang) yang telah memberikan dana penelitian. Terakhir, kepada dewan redaksi SEGARA serta pihak reviewer kami ucapkan pula terimakasih atas kerjasamanya hingga tulisan ini dapat diterbitkan. Kontributor utama dalam tulisan ini adalah Dino Gunawan Pryambodo.

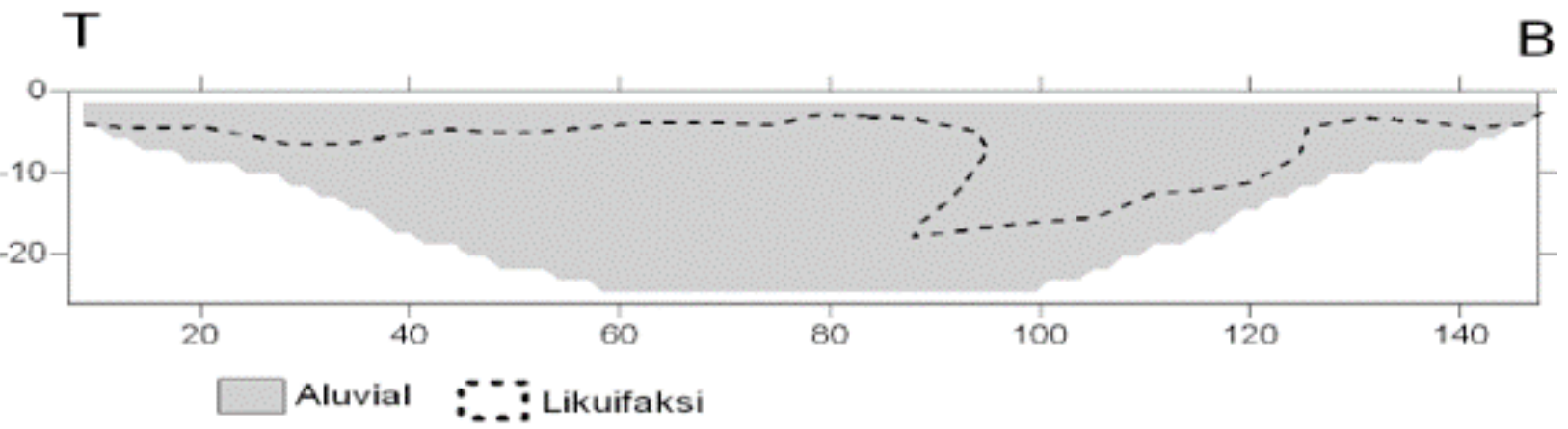

Gambar 15. Litologi Penampang Lintasan TELKOM. 


\section{DAFTAR PUSTAKA}

Barker, R.D. (1981), The offset system of electrical resistivity sounding and its use with a multicore cable. Geophysical Prospecting, 29(1), 128-143.

Chang C.H, Chien L.K., \& Chang Y.H., (2004). 3-D liquefaction potential analysis of seabed at nearshore area. J Mar Sci Technol, 12(3):141151.

Hasanudin. M., \& Pryambodo. D.G. (2009), Studi Intrusi Air Laut Di Cirebon Dengan Menggunakan Metode Geolistrik. Jurnal Segara, 5(2), 121-133.

Kastowo, Gerhard, W., Leo, S., Gafoer, S., \& Amin, T.C. (1994), Peta Geologi Lembar Padang, Sumatera Skala 1:250.000, Pusat Penelitian dan Pengembangan Geologi, Bandung,

Loke, M.H. (1999). Electrical Imaging Surveys for Environmental and Engineering Studies, Technical Notes. Geotomo Software, Malaysia,

Loke, M,H. (2001), Tutorial 2-D and 3-D electrical Imagine Survey, Geotomo Software, Malaysia,

Marpaung, H. (2000), Buku Pedoman Alat Resistivitymeter Naniura NRD-22 S, Bandung, 2000.

Milsom, J. (2003). Field Geophysics, Third Edition, John Wiley \& Sons Ltd,

Muntohar, A.S. (2010), Mikro-Zonazi Pempa Bum", Laporan Penelitian UMY Yogyakarta.

Natawidjaja, D.H., (2004), Paleogeodetic records of seismic and aseismic subduction from central Sumateran micro atolls, Indonesia, J.Geophys. Res, 109(B4).

Palacky, G.J. (1987). Resistivity characteristics of geologic targets", In Electromagnetic Methods in Applied Geophysics Theory, vol. 1. Society of Exploration Geophysicists, Tulsa, Okla.

Reynolds, J. (1977), An Introduction To Applied and environmental geophysics, John Wiley\&Sons,

Santoso, D. (2002). Pengantar Teknik Geofisika. Departemen Teknik Geofisika, ITB, 2002.

Setyonegoro. W. (2013). GEMPABUMI PADANG 30 SEPTEMBER 2009 DAN POTENSI TSUNAMINYA, Buletin Meteorologi Klimatologi dan Geofisika, 7(3), 163-171,

Syukri. M. (2011). Geoelectrical characterization for liquefaction at coastal zone in South Aceh, Proceedings of Annual International Conference Syiah Kuala University-Life Sciences \& Engineering Chapter, 1(2), 133-138

Telford, W.M., Geldart, L.P., \& Sheriff, R.E. (1990), Applied Geophysics, Second Edition, Cambridge and Hall, New York,

Tohari. A., Sugianti, K., \& Soebowo, E. (2011). Liquefaction potential at Padang City: a comparison of predicted and observed liquefactions during the 2009 Padang earthquake. Jurnal Riset Geologi dan Pertambangan, 21(1), 7-19. 
Identifikasi Likuifaksi Di Kawasan Pesisir ...... Metoda Geolistrik 2D (Pryambodo, D.G. \& Sudirman, N.) 